\title{
Introduction: the history of mathematics teaching. Indicators for modernization processes in societies
}

\author{
Gert Schubring • Fulvia Furinghetti • \\ Man Keung Siu
}

Published online: 12 July 2012

(C) FIZ Karlsruhe 2012

The history of mathematics education, i.e. of its teaching and learning, is a research field that has developed rapidly over the last decade. It is represented internationally, among others, by a dedicated journal, and by Topic Study Groups at the International Congresses on Mathematics Education since 2004. Several international congresses have documented the richness of ongoing research. In contrast with earlier traditional practice when it used to be restricted to accounts within specific national histories, present studies are no longer confined to administrational facts and descriptive tasks, but intend to unravel structural patterns and underlying political, social and cultural dimensions.

The invitation to prepare a Special Issue of ZDM presented a welcome opportunity for the guest editors to organize a volume which will be particularly revealing also for the broader community of mathematics educators. The starting point for the issue was not to review the state of the art for some specific countries, nor to aspire to some completeness either chronologically or geographically, given the long history of mathematics teaching and the number of countries around the world. Rather, we chose another approach, made possible by the adequate time-span

G. Schubring $(\bowtie)$

Universidade Federal do Rio de Janeiro,

Rio de Janeiro, RJ, Brazil

e-mail: gert.schubring@uni-bielefeld.de

F. Furinghetti

Dipartimento di Matematica,

Università di Genova, Genova, Italy

M. K. Siu

Department of Mathematics,

University of Hong Kong,

Hong Kong SAR, China given for elaborating this issue which thus allowed substantial research, namely to identify open problems in the history of mathematics education which are representative of the entire field, and to ask competent authors to undertake the necessary research.

As a common theme for these studies we chose modernization processes in mathematics teaching at periods of political and/or socio-cultural changes in several key countries. Particularly revealing are those cases where a traditional political order/society/culture is superseded by a more modern one, or at least is confronted with one claiming to be more modern. Since about the eighteenth century, regarding reforms in the educational system, mathematics has represented the progressive side, overcoming traditional restrictions and social segregations.

The outcomes of the undertaken research as presented in this issue reveal novel results about the role of mathematics teaching. As becomes clear from these case studies, establishing mathematics teaching proves to be intended as a means of modernizing the society to meet the demands with which the state in question is confronted. Indeed, it is through the actions of the empire or national state, not some individual's good will or the plans of a particular social group, that mathematics is ascribed a function within the intended reform process.

Most telling are studies of states suffering profound crises of their traditional modes of existing. In this issue we reveal the key functions ascribed to mathematics for refounding the basis of state and society in three empires: China, Japan and the Ottoman Empire. These all represent empires which used to be regarded as unchallenged powers, but-upon being confronted with Western values or even invasions - their traditional means proved no longer able to maintain their status. For example, as a consequence of the Second Opium War of Western powers 
against China, the reformers in the government formulated their basic conviction for reforming China and being able to resist the invaders, by adopting Western science and education:

All Western knowledge is derived from mathematics. Every Westerner of ten years of age or more studies mathematics. If we now wish to adopt Western knowledge, naturally we cannot but learn mathematics. (Siu and Chan 2012)

The Ottoman Empire, traditionally an expansionist power, suffered defeats during the second half of the eighteenth century in the Balkans. Reform-minded sultans consequently established engineering and military schools privileging mathematics teaching. Likewise, similar reforms were undertaken by the partially dependent, partially independent governments of Tunisia and Egypt. And it is characteristic that the then still strong traditional social forces directed their destructions in particular against the new schools.

In such situations of crisis, the state and its government concentrates on its most urgent needs for maintaining its existence and strength: on engineering and on warfare capacities. It is thus revealing that the first functions of mathematics for the state are its technical and military applications. Yet, we see that — in a second step - the state becomes the agent of teaching mathematics as a key element of general education. Japan presents a telling example for these two steps. First, even before the opening of Japan to the West by the 1867 Meiji fundamental change of policy, the central government had founded a Naval Academy at Nagasaki, in 1855, "where Western mathematics was taught because of its military applications" (Ueno 2012). Second, as part of its profound reforms of society from 1867 on, in particular of abolishing the feudal clans system and their segregated school structures, the new government established a centralized educational system for all, with mathematics as a basic constituent.

Brazil presents a case characteristic of the complicated ways in which a country develops. For centuries, the colonial power Portugal was just interested in extracting goods (including gold and silver) and did not establish educational structures. However, when Brazil became the residence of the Portuguese king in 1808, one of the first measures for its development was the founding of a military academy, with mathematics as its fundamental discipline. For a long time, while promoting post-secondary professional training, the Imperial government did not take decisive measures for establishing a general educational system, and the practice of "isolated exams" made it possible to complete the requirements for entrance to postsecondary education by taking the necessary exams without having attended a regular secondary school course.
Even in the times of the Republic, from 1889, schooling was left to particular initiatives within the federal states. It was only from the 1930 s on, due to a decisive break with traditional policy, that centralized organization of an effective school system became enforced, in parallel with a strong industrialization of the economy, and then a strictly modernized teaching of mathematics was decreed.

Germany, with its multitude of sovereign states, presented during the nineteenth century an antagonistic pattern. Prussia, although still based on an agrarian economy and far from an industrial revolution, had enacted profound educational reforms which anticipated such a revolutionand thus provided the formation which enabled bringing about the industrial take-off. The majority of the other states, however, persisted in the traditional educational structures. As Friedrich Paulsen, the famous historian of education, has described his education at a classical Gymnasium in Holstein, the major goal of the students was to achieve the "color Latinus", the genuine Latinity:

Nothing occurred, which could have made us doubting in this. We confidently disprized the modern languages; they are for the merchant, not for the scholar; we disdained mathematics and we knew nothing of the sciences; and of technique and industry nobody in our context ever spoke. (Schubring 2012)

It was the political dynamics of Prussia, extending its territories and allying with other states, which eventually brought about an adaptation of the educational systems. Tellingly, it was again military needs which initiated the coordination of formerly incompatible curricula.

On the other hand, it is not each state which acts in such a modernizing, improving way. States have to undergo structural transformations to be able to assume such novel societal tasks. This issue presents two examples of this, from France and Italy.

One dimension where many states for a long time hesitated or even refused to assume responsibilities was primary education. Or perhaps, rather, they catered only for the education of middle and upper classes-the future leaders-not for the education of the lower classes. Founding primary schools in the entire country had been the primordial goal after the French Revolution, but too many obstacles arose so the secondary schools were organized first. Primary schools became a definite issue of state policy only from the Liberal Revolution of 1830 on, overcoming the conservative Restoration of 1815. Then, teacher training for primary schools constituted a key issue of government policy in education, and their institutions expanded strongly. However, after the 1848 Revolution and the ensuing conservative backlash, primary school teachers and the teacher training institutes were accused of having sown social unrest and were almost closed. When 
they continued, from 1850 , they suffered a strict reduction to just very elementary training goals.

Another example is provided by Italy. The political unification into just one state in 1861 led both to a remarkable rise in mathematical research and to a state policy regarding the education system, which, however, not used to be coherent and dynamic. Particularly suffering from shortcomings was teacher education, which was not provided on a large scale and even only lately, in 1875 . Italy presents the unique case in which institutions for teacher training were not only threatened to be suppressed, like in France, but actually dissolved, in 1920. After that, for many years, teacher training was neglected by the Ministry of Education as a consequence of the dominant idealistic philosophy, in which mathematics and the sciences were suspect, and which, in general, identified knowing the subject with knowing how to teach it.

A completely different, but likewise revealing, example of modernization processes is when a political revolution seems to open the way for realizing all utopias. This was the case with Russia after the October Revolution and in the early times of the Soviet Union, when pedagogical reformers set out to establish a fundamentally restructured education system. Starting from a vision of learning based in processes of labour, mathematics was valued only insofar as it was able to contribute to solving practical problems. According to this revolutionary conception, mathematics should not be taught as a proper school discipline.

The concluding contribution of this issue shows a novel dimension of modernization processes. So far, they had been restricted to individual states, following a logic of the state's internal development. The first international reform movement for mathematics teaching, initiated from 1908 by IMUK/CIEM, implied a certain coordination, but remained strictly confined to (relatively independent) national movements, adopting specific reform stances. In contrast, the international reform movement after 1958, superseding already ongoing particular reform movements in various countries, constituted an unprecedented manner of reform processes, effecting really concerted actionswhile there were differing foci and realizations of the reform goals, the general conceptions kept pace in a great number of countries. Moreover, provoked by the challenge to its political system, usually coined "Sputnik shock", the West undertook it consciously to decisively modernize its educational systems to meet this challenge. And it was again mathematics which was conceived of as the prime agent of modernizing change, as is evident from the actions of the Organization for European Economic Cooperation (OEEC, later renamed OECD: Organization for Economic Cooperation and Development) in initiating and orchestrating this international movement, undertaking as its first action to meet the Sputnik shock the organization of the famous Royaumont seminar in 1959, which launched the movement of modern mathematics. Similar actions of OEEC for physics and for chemistry followed only later.

\section{References}

Schubring, G. (2012). Antagonisms between German states regarding the status of mathematics teaching during the 19th centuryprocesses of reconciling them. ZDM The International Journal on Mathematics Education, 44(4). doi:10.1007/s11858-0120407-0.

Siu, M. K., \& Chan, Y. C. (2012). Facing the change and meeting the challenge: mathematics curriculum of Tongwen Guan in China in the second half of the nineteenth century. ZDM The International Journal on Mathematics Education, 44(4). doi: 10.1007/s11858-012-0427-9.

Ueno, K. (2012). Mathematical teaching before and after the Meiji Restoration. ZDM The International Journal on Mathematics Education, 44(4). doi:10.1007/s11858-012-0443-9. 